\title{
APPLICATION OF WASPAS METHOD IN THE EVALUATION OF EFFICIENCY OF AGRICULTURAL ENTERPRISES IN SERBIA
}

\author{
Radojko Lukić1, Dragana Vojteski Kljenak ${ }^{2}$, Slavica Anđelić3, Milan Gavrlilović ${ }^{4}$ \\ *Corresponding author E-mail: rlukic@ekof.bg.ac.rs
}

A R T I C L E I N F O
Original Article
Received: 13 March 2021
Accepted: 28 May 2021
doi:10.5937/ekoPolj2102375L

UDC 332.155:338.432(497.11)

Keywords:

efficiency, agricultural enterprises of Serbia, determinants, AHP - WASPAS method

\begin{abstract}
A B S T R A C T
Recently, as it is known, the evaluation of the efficiency of agricultural enterprises is being more and more performed on the basis of multi-criteria analysis. With this in mind, this paper analyzes the efficiency of agricultural enterprises in Serbia based on the WASPAS method. The goal and purpose of this is to address this issue as thoroughly as possible and propose adequate measures to improve the efficiency of agricultural enterprises in Serbia in the future. The obtained results of empirical research using the given method show that the efficiency of agricultural enterprises in Serbia has recently significantly improved. It was the best in 2018. It was positively influenced by numerous macro and micro factors.
\end{abstract}

(C) 2021 EA. All rights reserved.

\section{Introduction}

The issue of measuring the efficiency of agricultural enterprises based on multi-criteria analysis is very current, complex and significant (Lukic, 2011; Lukic, 2018; Turskis, 2015, Vojteski Kljenak, 2019; Zhang, 2020; Bakić, 2020). Given this, the subject of research in this paper is the analysis of the efficiency of agricultural enterprises in Serbia based on the WASPAS method. The goal and purpose of this is to address this issue as thoroughly as possible and propose adequate measures to improve the efficiency of agricultural enterprises in Serbia in the future. This, among other things, reflects the

1 Radojko Lukić, Ph.D., Full Professor, University of Belgrade Faculty of Economics, Kamenica 6, Belgrade Republic of Serbia, Phone: +381 1130211 12, E-mail: rlukic@ekof. bg.ac.rs, ORCID ID (https://orcid.org/0000-0001-6529-0297)

2 Dragana Vojteski Kljenak, Ph.D., Associate Professor, Faculty of Business Economics and Entrepreneurship, Mitropolita Petra 8, Belgrade, Republic of Serbia, Phone: +381 112762 194, E-mail: vojteski@live.co.uk, ORCID ID (https://orcid.org/0000-0002-5707-1585)

3 Slavica Anđelić, Ph.D., Associate Professor, Faculty of Business Economics and Entrepreneurship, Mitropolita Petra 8, Belgrade, Republic of Serbia, Phone: +381 112762 194, E-mail: slavicaandjel@gmail.com, ORCID ID (https://orcid.org/0000-0003-4021-0822)

4 Milan Gavrilović, Ph.D., Assistant Professor, Faculty of Business Economics and Entrepreneurship, Mitropolita Petra 8, Belgrade, Republic of Serbia, Phone: +381 112762 194, E-mail: gavrilovicmilan82@gmail.com, ORCID ID (https://orcid.org/0000-0002-0130-6496) 
scientific and professional contribution of this paper.

Recently, as it is known, an increasingly rich literature is dedicated to the analysis of the efficiency of companies from different economic sectors based on the WASPAS method. However, there are very few works of this type from the agricultural sector in Serbia (Chavas, 1993; Ashkan Hafezalkotob, 2018; Kolagar, 2019; Kutlu, 2019; Lukic, 2019, 2020a, b, c, d, e, f). In other words, in the literature in Serbia, there is, as far as we know, no comprehensive work dedicated to the analysis of the efficiency of agricultural enterprises in Serbia based on the WASPAS method (Petrovic, 2019). In this paper, based on the reputation of contemporary foreign literature, the efficiency analysis of agricultural enterprises in Serbia is performed using the WASPAS method for the first time. And that, among other things, reflects the scientific and professional contribution of this paper.

Research through the literature in this paper serves as a theoretical, methodological and empirical basis for a proper analysis of the efficiency of agricultural enterprises in Serbia based on the WASPAS method.

The basic hypothesis of the research in this paper is that continuous monitoring of the efficiency of agricultural enterprises is a prerequisite for improvement in the future: in our case in Serbia. This facilitates and indicates what adequate measures should be taken to achieve the target efficiency of agricultural enterprises in Serbia. In this, in the methodological sense of the word, the application of the WASPAS method plays a significant role.

The research is based on data from the Business Registers Agency of the Republic of Serbia, "produced" in accordance with relevant international standards and comparable globally. There are therefore no restrictions in this regard.

\section{Materials and methods}

WASPAS (Weighted Aggregates Sum Product Assessment) was proposed by Zavadskas et al. (2012). It respects the unique combination of two well-known approaches to multi-criteria decision making (MCDM): the Weighted Sum method (WS) and the Weighted Product method (WP). The WASPAS method is used to solve various complex problems in multicriteria decision making (e.g., production decision making) (Chakraborty, 2014; Zavadskas, 2013a). An advanced fuzzy WASPAS method has been developed to solve complex problems in the face of uncertainty.

The WASPAS method procedure consists of the following steps (Urosevic, 2017):

Step 1. Determine the optimal performance rating for each criterion.

The optimal performance rating is calculated as follows:

$$
x_{0 j}=\left\{\begin{array}{ll}
\max _{i} x_{i j} ; & j \in \Omega_{\max } \\
\min _{i} x_{i j} ; & j \in \Omega_{\min }
\end{array},\right.
$$


where:

$x_{0 j}$ denotes the optimal performance rating of the $i$-th criterion,

$\Omega_{\max }$ denotes the benefit criterion (the higher the value, the better),

$\Omega_{\min }$ denote a set of cost criteria (the lower the value, the better),

$m$ denotes the number of alternatives $(i=0,1, \ldots, m)$, and

$n$ denotes the number of criteria $(j=0,1, \ldots, n)$.

Step 2. Determine the normalized decision matrix.

The normalized performance rating is calculated as follows:

$r_{i j}=\left\{\begin{array}{ll}\frac{x_{i j}}{x_{0 j}} ; & j \in \Omega_{\max } \\ \frac{x_{0 j}}{x_{i j}} ; & j \in \Omega_{\min }\end{array}\right.$,

where:

$r_{i j}$ denotes the normalized performance rating of the $i$-th alternative in relation to the $j$-th criterion.

method.

Step 3. Calculate the relative importance of the $i$-th alternative based on the WS The relative importance of the $i$-th alternative, based on the WS method, is calculated as follows:

$Q_{i}^{(1)}=\sum_{j=1}^{n} w_{j} r_{i j}$,

where:

$Q_{i}^{(1)}$ denotes the relative importance of the $i$-th alternative in relation to the $j$-th criterion, based on the WS method.

WP method.

Step 4. Calculate the relative importance of the $i$-th alternative, based on the The relative importance of the $i$-th alternative, based on the WP method, is calculated as follows:

$Q_{i}^{(2)}=\prod_{j=1}^{n} r_{i j}^{w_{j}}$, 
where:

$Q_{i}^{(2)}$ denotes the relative importance of the $i$-th alternative in relation to the $j$-th criterion, based on the WP method.

Step 5. Calculate the total relative significance for each alternative.

The total relative significance (common generalized criterion of weight aggregations of additive and multiplicative methods) (Zavadskas, 2012), is calculated as follows:

$$
Q_{i}=\lambda Q_{i}^{(1)}+(1-\lambda) Q_{i}^{(2)}=\lambda \sum_{j=1}^{n} w_{j} r_{i j}+(1-\lambda) \prod_{j=1}^{n} r_{i j}^{w_{j}}
$$

where:

$\lambda$ coefficient $\lambda \in[0,1]$.

When decision makers do not have preferences over the coefficient, the value is 0.5 , and equation (5) is expressed as:

$$
Q_{i}=0.5 Q_{i}^{(1)}+0.5 Q_{i}^{(2)}=0.5 \sum_{j=1}^{n} w_{j} r_{i j}+0.5 \prod_{j=1}^{n} r_{i j}^{w_{j}}
$$

In this paper, for the purposes of applying the WASPAS method in the evaluation of the efficiency of agricultural enterprises in Serbia, the weighting coefficients are determined on the basis of the AHP (Analytical Hierarchical Process) method. With this in mind, we will briefly review the theoretical characteristics of the AHP method. The Analytical Hierarchical Process (AHP) method includes the following steps (Saaty, 2008):

Step 1: Forming a pair-wise comparison matrix

$$
A=\left[a_{i j}\right]=\left[\begin{array}{cccc}
1 & a_{12} & \cdots & a_{1 n} \\
1 / a_{12} & 1 & \cdots & a_{2 n} \\
\cdots & \cdots & \cdots & \cdots \\
1 / a_{1 n} & 1 / a_{2 n} & \cdots & 1
\end{array}\right]
$$

Step2: Normalizing the pair-wise comparison matrix

$$
a_{i j}^{*}=\frac{a_{i j}}{\sum_{i=1}^{n} a_{i j}}, i, j=1, \ldots, n
$$

Step 3: Determining the relative importance, i.e. the weight vector

$$
w_{i}=\frac{\sum_{i=1}^{n} a_{i j}^{*}}{n}, i, j=1, \ldots, n
$$

Consistency index - CI (consistency index) is a measure of deviation $n$ from $\lambda_{\max }$ and can be represented by the following formula: 


$$
C I=\frac{\lambda_{\max }-n}{n}
$$

If $\mathrm{CI}<0.1$, the estimated values of the coefficients $a_{i j}$ are consistent, and the deviation $\lambda_{\max }$ from $n$ is negligible. This means, in other words, that the AHP method accepts an inconsistency of less than $10 \%$.

Using the consistency index, the consistency ratio $\mathrm{CR}=\mathrm{CI} / \mathrm{RI}$ can be calculated, where RI is a random index.

\section{Results and Discussion}

When measuring the efficiency of agricultural enterprises in Serbia using the WASPAS method, the following criteria were taken: C1 - number of employees, C2 - assets, C3 - capital, C4 - operating income and C5 - net profit. Alternatives were observed in the years: A1 - 2013, A2 - 2014, A3 - 2015, A4 - 2016, A5 - 2017, A6 - 2018 and A7 2019 (Calculation of the efficiency of agricultural enterprises in Serbia was performed using the WASPASSoftware-Excel). The obtained results are shown in the tables and figures below. Table 1 shows the initial data for measuring the efficiency of agricultural enterprises in Serbia for the period 2013 - 2019.

Table 1. Initial data for measuring the efficiency of agricultural enterprises in Serbia

\begin{tabular}{|l|l|l|l|l|l|}
\hline & $\begin{array}{l}\text { Number of } \\
\text { employees }\end{array}$ & Assets & Capital & $\begin{array}{l}\text { O p e r a t i n g } \\
\text { income }\end{array}$ & Net profit \\
\hline 2013 & 36015 & 570352 & 305601 & 315477 & 21418 \\
\hline 2014 & 33256 & 641869 & 353052 & 316220 & 17515 \\
\hline 2015 & 33498 & 688188 & 382718 & 321608 & 16960 \\
\hline 2016 & 32244 & 781508 & 480683 & 352715 & 20392 \\
\hline 2017 & 32023 & 815393 & 508124 & 330809 & 20936 \\
\hline 2018 & 32330 & 846778 & 523357 & 349616 & 32466 \\
\hline 2019 & 31247 & 874451 & 544362 & 350328 & 19932 \\
\hline
\end{tabular}

Note: The number of employees is expressed in whole numbers. The data are expressed in millions of dinars. Companies from the agriculture, forestry and fisheries sectors are included.

Source: Serbian Business Registers Agency

Table 2 shows descriptive statistics of initial data for measuring the efficiency of agricultural enterprises in Serbia. 
Table 2. Descriptive Statistics

\begin{tabular}{|c|c|c|c|c|}
\hline \multicolumn{5}{|l|}{ Descriptive Statistics } \\
\hline & $\mathrm{N}$ & Minimum & Maximum & Mean \\
\hline 1 Number of employees & 7 & 31247.00 & 36015.00 & 32944.7143 \\
\hline 2 Assets & 7 & 570352.00 & 874451.00 & 745505.5714 \\
\hline 3 Capital & 7 & 305601.00 & 544362.00 & 442556.7143 \\
\hline 4 Operating income & 7 & 315477.00 & 352715.00 & 333824.7143 \\
\hline 5 Net profit & 7 & 16960.00 & 32466.00 & 21374.1429 \\
\hline Valid N (listwise) & 7 & & & \\
\hline
\end{tabular}

Source: Author's calculation done by using the SPSS software program

Data from descriptive statistics show that in 2018, the best performances of agricultural companies were in Serbia. Net profit was above average.

Table 3 shows the correlation matrix of initial data used to measure the efficiency of agricultural enterprises in Serbia.

Table 3. Correlation matrix

\begin{tabular}{|c|c|c|c|c|c|}
\hline \multicolumn{6}{|l|}{ Correlations } \\
\hline & & 1 & 2 & 3 & 4 \\
\hline \multirow{3}{*}{$\begin{array}{l}1 \text { Number of } \\
\text { employees }\end{array}$} & Pearson Correlation & 1 & $-.918^{* *}$ & $-.905^{* *}$ & -.749 \\
\hline & Sig. (2-tailed) & & .004 & .005 & .053 \\
\hline & $\mathrm{N}$ & 7 & 7 & 7 & 7 \\
\hline \multirow{3}{*}{2 Assets } & Pearson Correlation & $-.918^{* *}$ & 1 & $.996^{* *}$ & $.868^{*}$ \\
\hline & Sig. (2-tailed) & .004 & & .000 & .011 \\
\hline & $\mathrm{N}$ & 7 & 7 & 7 & 7 \\
\hline \multirow{3}{*}{3 Capital } & Pearson Correlation & $-.905^{* *}$ & $.996^{* *}$ & 1 & $.879^{* *}$ \\
\hline & Sig. (2-tailed) & .005 & .000 & & .009 \\
\hline & $\mathrm{N}$ & 7 & 7 & 7 & 7 \\
\hline \multirow{3}{*}{$\begin{array}{l}4 \text { Operating } \\
\text { income }\end{array}$} & Pearson Correlation & -.749 & $.868^{*}$ & $.879^{* *}$ & 1 \\
\hline & Sig. (2-tailed) & .053 & .011 & .009 & \\
\hline & $\mathrm{N}$ & 7 & 7 & 7 & 7 \\
\hline \multirow{3}{*}{5 Net profit } & Pearson Correlation & -.141 & .429 & .441 & .491 \\
\hline & Sig. (2-tailed) & .763 & .337 & .322 & .264 \\
\hline & $\mathrm{N}$ & 7 & 7 & 7 & 7 \\
\hline \multicolumn{6}{|c|}{ **. Correlation is significant at the 0.01 level (2-tailed). } \\
\hline \multicolumn{6}{|c|}{ *. Correlation is significant at the 0.05 level (2-tailed). } \\
\hline
\end{tabular}

Source: Author's calculation done by using the SPSS software program

There is a significant correlation between the initial data, apart from net profit. In order to increase the efficiency of agricultural enterprises in Serbia in the future, it is necessary to manage profits as efficiently as possible. In addition to efficient marketing management, the application of modern concepts of cost management in agricultural companies in Serbia has a significant role in that. 
Table 4 and Figure 1, in order to make the efficiency analysis as complex as possible, show the ratio analysis of agricultural enterprises in Serbia.

Table 4. Ratio analysis

\begin{tabular}{|l|l|l|l|l|}
\hline & $\begin{array}{l}\text { Profit per employee } \\
\text { (Net profit / Number of } \\
\text { employees) (in thousands } \\
\text { of dinars) }\end{array}$ & $\begin{array}{l}\text { Return on assets } \\
\text { (Net profit / } \\
\text { Assets) }\end{array}$ & $\begin{array}{l}\text { Return on equity } \\
\text { (Net profit / } \\
\text { Capital) }\end{array}$ & $\begin{array}{l}\text { Return on operating } \\
\text { income (Net profit / } \\
\text { Operating income) }\end{array}$ \\
\hline 2013 & 594.6967 & $3.76 \%$ & $7.01 \%$ & $6.79 \%$ \\
\hline 2014 & 526.6719 & $2.73 \%$ & $4.96 \%$ & $5.54 \%$ \\
\hline 2015 & 506.2989 & $2.46 \%$ & $4.43 \%$ & $5.27 \%$ \\
\hline 2016 & 632.4277 & $2.61 \%$ & $4.24 \%$ & $5.78 \%$ \\
\hline 2017 & 653.7801 & $2.57 \%$ & $4.12 \%$ & $6.33 \%$ \\
\hline 2018 & 1004.207 & $3.83 \%$ & $6.20 \%$ & $9.29 \%$ \\
\hline 2019 & 637.8852 & $2.28 \%$ & $3.66 \%$ & $5.69 \%$ \\
\hline
\end{tabular}

Source: Author's calculations

Figure 1. Ratio analysis

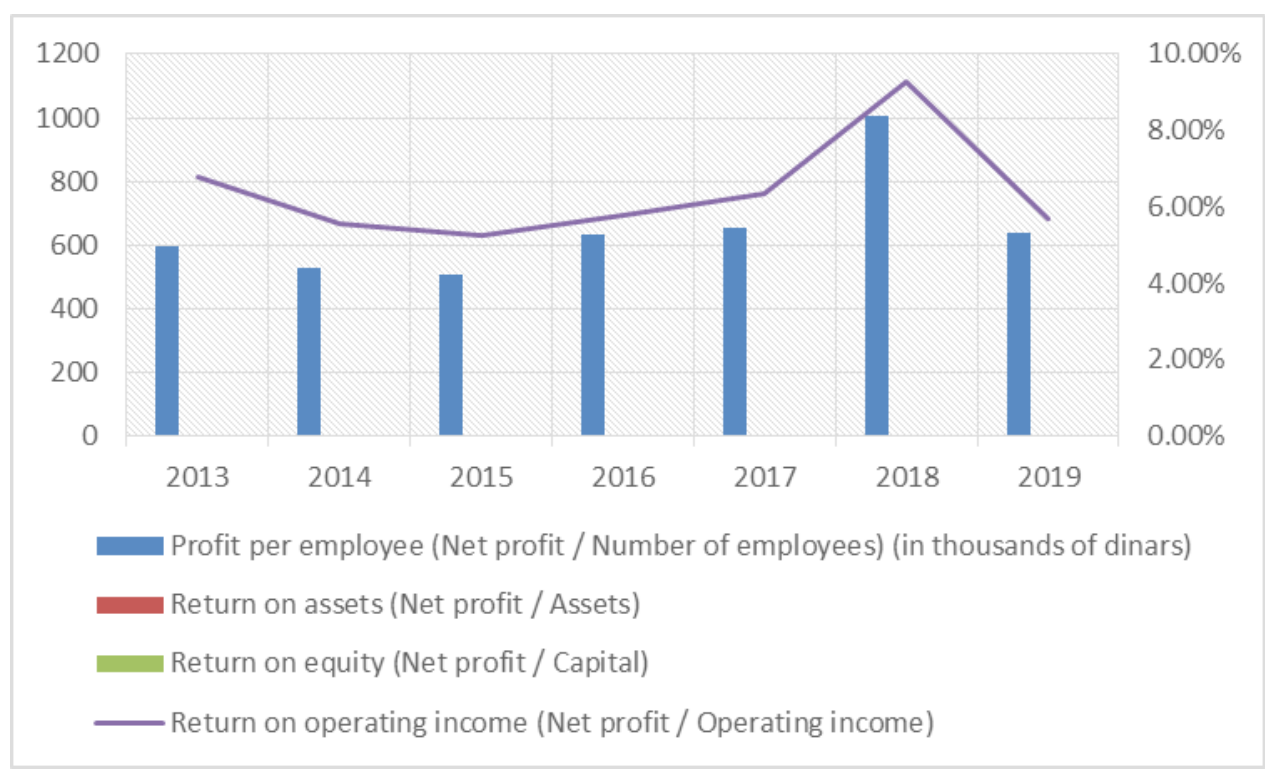

Source: Author's calculations

The ratio analysis shows that the best performances of agricultural companies in Serbia were in 2018. In that year, for example, the highest profit per employee was achieved.

The weighting coefficients of the criteria are shown in Table 5 and Figure 2. They were determined using the AHP method. (The calculation was performed using the software program AHPSoftware-Excel.) 
Table 5. The weighting coefficients of the criteria

\begin{tabular}{|l|l|l|l|}
\hline \multirow{5}{*}{ Table } & \multicolumn{2}{|l|}{ Criterion } & Weights \\
\cline { 2 - 5 } & 1 & Number of employees & $28.4 \%$ \\
\cline { 2 - 4 } & 2 & Assets & $18.4 \%$ \\
\cline { 2 - 4 } & 3 & Capital & $13.2 \%$ \\
\cline { 2 - 4 } & 4 & Sales & $33.2 \%$ \\
\cline { 2 - 4 } & 5 & Net profit & $6.8 \%$ \\
\hline
\end{tabular}

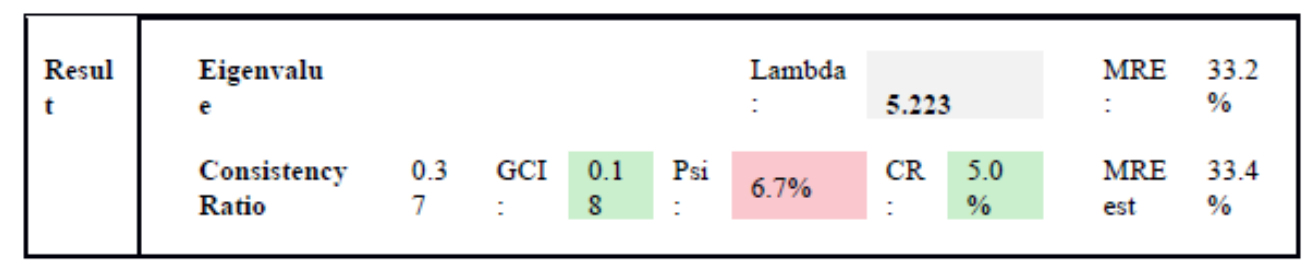

\begin{tabular}{|c|c|c|c|c|c|c|c|}
\hline Matrix & & $\begin{array}{c}\text { Number } \\
\text { of } \\
\text { employees }\end{array}$ & Assets & Capital & Sales & $\begin{array}{c}\text { Net } \\
\text { profit }\end{array}$ & $\begin{array}{l}\text { normalized principal } \\
\text { Eigenvector }\end{array}$ \\
\hline & & 1 & 2 & 3 & 4 & 5 & \\
\hline $\begin{array}{l}\text { Number of } \\
\text { employees }\end{array}$ & 1 & 1 & 2 & 3 & $1 / 2$ & 4 & $28.43 \%$ \\
\hline Assets & 2 & $1 / 2$ & 1 & 2 & $1 / 2$ & 3 & $18.37 \%$ \\
\hline Capital & 3 & $1 / 3$ & $1 / 2$ & 1 & $1 / 2$ & 3 & $1318 \%$ \\
\hline Sales & 4 & 2 & 2 & 2 & 1 & 3 & $33.23 \%$ \\
\hline Net profit & 5 & $1 / 4$ & $1 / 3$ & $1 / 3$ & $1 / 3$ & 1 & $6.80 \%$ \\
\hline
\end{tabular}

Source: Author's calculation using AHPSoftware-Excel 
Figure 2. Weighting coefficients of the criteria

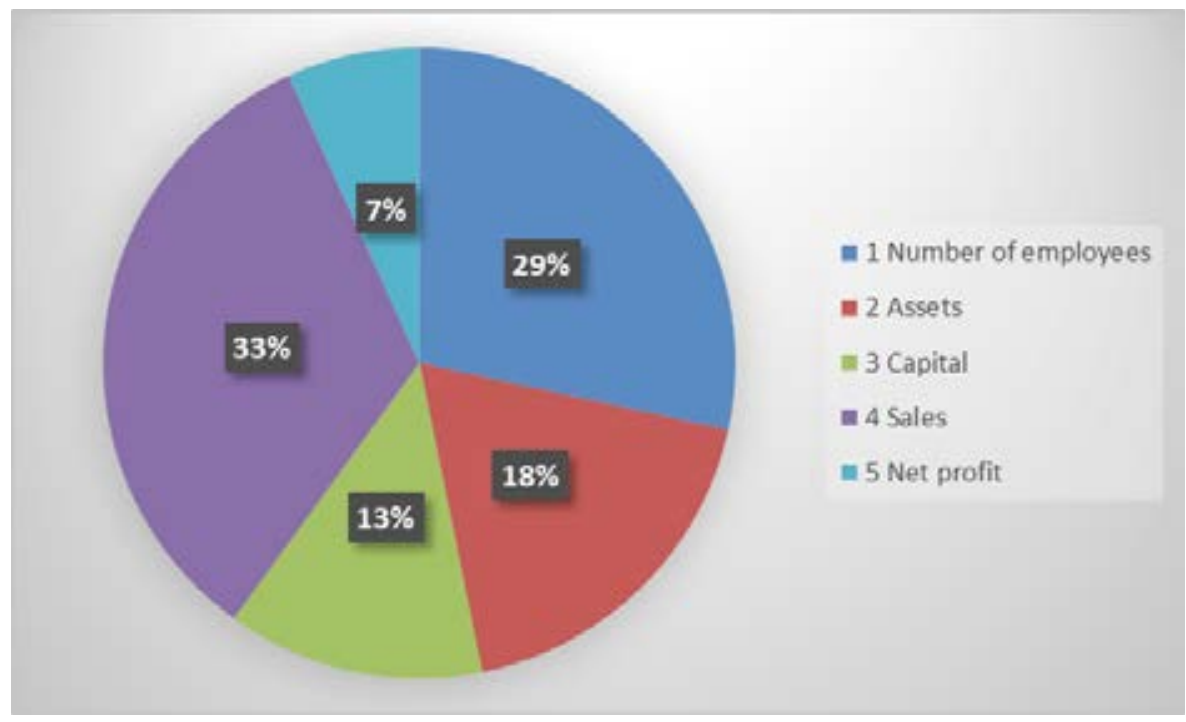

Source: Authors' calculations

According to the importance of the observed criteria, sales come first. They follow in order: number of employees, assets, capital and net profit. This means that improving sales management can significantly affect the efficiency of agricultural enterprises in Serbia.

The initial decision matrix is shown in Table 6.

Table 6. Initial matrix

\begin{tabular}{|l|l|l|l|l|l|}
\hline Initial matrix & & & & & \\
\hline weights of criteria & 0.284 & 0.184 & 0.132 & 0.332 & 0.068 \\
\hline kind of criteria & 1 & 1 & 1 & 1 & 1 \\
\hline & C1 & C2 & C3 & C4 & C5 \\
\hline A1 & 36015 & 570352 & 305601 & 315477 & 21418 \\
\hline A2 & 33256 & 641869 & 353052 & 316220 & 17515 \\
\hline A3 & 33498 & 688188 & 382718 & 321608 & 16960 \\
\hline A4 & 32244 & 781508 & 480683 & 352715 & 20392 \\
\hline A5 & 32023 & 815393 & 508124 & 330809 & 20936 \\
\hline A6 & 32330 & 846778 & 523357 & 349616 & 32466 \\
\hline A7 & 31247 & 874451 & 544362 & 350328 & 19932 \\
\hline MAX & 36015 & 874451 & 544362 & 352715 & 32466 \\
\hline MIN & 31247 & 570352 & 305601 & 315477 & 16960 \\
\hline
\end{tabular}

Source: Authors' calculations 
The normalized decision matrix is shown in Table 7.

Table 7. Normalized matrix

\begin{tabular}{|l|l|l|l|l|l|}
\hline Normalized matrix & & & & & \\
\hline weights of criteria & 0.284 & 0.184 & 0.132 & 0.332 & 0.068 \\
\hline kind of criteria & 1 & 1 & 1 & 1 & 1 \\
\hline & C1 & C2 & C3 & C4 & C5 \\
\hline A1 & 1.0000 & 0.6522 & 0.5614 & 0.8944 & 0.6597 \\
\hline A2 & 0.9234 & 0.7340 & 0.6486 & 0.8965 & 0.5395 \\
\hline A3 & 0.9301 & 0.7870 & 0.7031 & 0.9118 & 0.5224 \\
\hline A4 & 0.8953 & 0.8937 & 0.8830 & 1.0000 & 0.6281 \\
\hline A5 & 0.8892 & 0.9325 & 0.9334 & 0.9379 & 0.6449 \\
\hline A6 & 0.8977 & 0.9684 & 0.9614 & 0.9912 & 1.0000 \\
\hline A7 & 0.8676 & 1.0000 & 1.0000 & 0.9932 & 0.6139 \\
\hline
\end{tabular}

Source: Authors' calculations

The weighted normalized decision matrix is shown in Table 8.

Table 8. Weighted normalized matrix

\begin{tabular}{|l|l|l|l|l|l|l|}
\hline $\begin{array}{l}\text { Weighted normalized } \\
\text { matrix }\end{array}$ & & & & & & \\
\hline & C1 & C2 & C3 & C4 & C5 & Qi1 \\
\hline A1 & 0.2840 & 0.1200 & 0.0741 & 0.2969 & 0.0449 & 0.8199 \\
\hline A2 & 0.2622 & 0.1351 & 0.0856 & 0.2976 & 0.0367 & 0.8172 \\
\hline A3 & 0.2642 & 0.1448 & 0.0928 & 0.3027 & 0.0355 & 0.8400 \\
\hline A4 & 0.2543 & 0.1644 & 0.1166 & 0.3320 & 0.0427 & 0.9100 \\
\hline A5 & 0.2525 & 0.1716 & 0.1232 & 0.3114 & 0.0439 & 0.9025 \\
\hline A6 & 0.2549 & 0.1782 & 0.1269 & 0.3291 & 0.0680 & 0.9571 \\
\hline A7 & 0.2464 & 0.1840 & 0.1320 & 0.3298 & 0.0417 & 0.9339 \\
\hline
\end{tabular}

Source: Authors' calculations

Table 9 shows the exponentially weighted decision matrix. 
Table 9. Exponentially weighted matrix

\begin{tabular}{|l|l|l|l|l|l|l|}
\hline $\begin{array}{l}\text { Exponentially } \\
\text { weighted matrix }\end{array}$ & C1 & C2 & C3 & C4 & C5 & Qi2 \\
\hline A1 & 1.0000 & 0.9244 & 0.9266 & 0.9636 & 0.9721 & 0.8024 \\
\hline A2 & 0.9776 & 0.9447 & 0.9444 & 0.9644 & 0.9589 & 0.8066 \\
\hline A3 & 0.9796 & 0.9569 & 0.9546 & 0.9698 & 0.9568 & 0.8303 \\
\hline A4 & 0.9691 & 0.9795 & 0.9837 & 1.0000 & 0.9689 & 0.9047 \\
\hline A5 & 0.9672 & 0.9872 & 0.9909 & 0.9789 & 0.9706 & 0.8990 \\
\hline A6 & 0.9698 & 0.9941 & 0.9948 & 0.9971 & 1.0000 & 0.9563 \\
\hline A7 & 0.9605 & 1.0000 & 1.0000 & 0.9977 & 0.9674 & 0.9270 \\
\hline
\end{tabular}

Source: Authors' calculations

Table 10 and Figure 3 show the ranking of alternatives.

Table 10. Ranking of alternatives

\begin{tabular}{|l|l|l|l|l|l|l|l|}
\hline & Ranking & & & & $\lambda$ & $\mathbf{0 . 5}$ & \\
\cline { 2 - 7 } & Alternatives & Qi1 & Qi2 & Qi & Qi & Ranking \\
\hline 2013 & A1 & 0.8199 & 0.8199 & 0.8199 & 0.8199 & $\mathbf{6}$ \\
\hline 2014 & A2 & 0.8172 & 0.8172 & 0.8172 & 0.8172 & $\mathbf{7}$ \\
\hline 2015 & A3 & 0.8400 & 0.8400 & 0.8400 & 0.8400 & $\mathbf{5}$ \\
\hline 2016 & A4 & 0.9100 & 0.9100 & 0.9100 & 0.9100 & $\mathbf{3}$ \\
\hline 2017 & A5 & 0.9025 & 0.9025 & 0.9025 & 0.9025 & $\mathbf{4}$ \\
\hline 2018 & A6 & 0.9571 & 0.9571 & 0.9571 & 0.9571 & $\mathbf{1}$ \\
\hline 2019 & A7 & 0.9339 & 0.9339 & 0.9339 & 0.9339 & $\mathbf{2}$ \\
\hline
\end{tabular}

Source: Authors' calculations

Figure 3. Ranking of alternatives

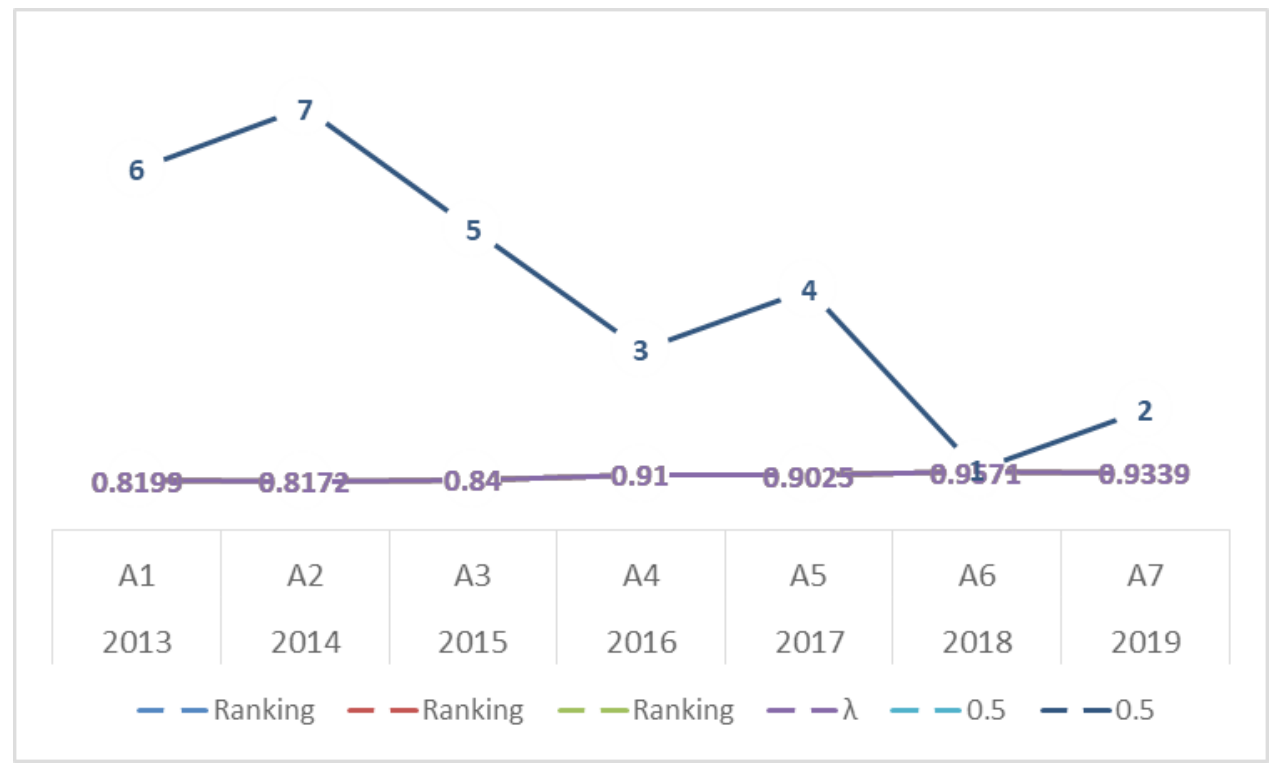

Source: Authors' calculations 
The obtained results of the research on the efficiency problems of agricultural enterprises in Serbia on the basis of the WASPAS method show that the highest efficiency was achieved in 2018. They are therefore identical with the results of descriptive statistics and ratio analysis. The order of all other years is as follows: 2019, 2016, 2017, 2015, 2013 and 2014. The efficiency of agricultural enterprises in Serbia has been at a satisfactory level lately. This was positively influenced by numerous macro and micro factors (general economic conditions, stable exchange rate, low inflation, low bank interest rate, subsidies and grants, reduced unemployment rate, increased living standards, regulation of the labor market of farmers, increasing understanding of the importance of insuring agriculture from adverse climate change, increased placement of agricultural products on foreign markets and branding of agricultural products. general economic conditions, stable exchange rate, low inflation, low bank interest rate, subsidies and grants, reduced unemployment rate, increased living standards, regulation of the labor market of farmers, increasing understanding of the importance of insuring agriculture from adverse climate change, increased placement of agricultural products on foreign markets and branding of agricultural products, increased production of organic products, application of modern technology in agriculture).

\section{Conclusions}

Based on the conducted analysis of the efficiency of agricultural enterprises in Serbia on the basis of the WASPAS method, the following can be concluded:

Agricultural companies in Serbia were the most efficient in 2018. The order of all other years is as follows: 2019, 2016, 2017, 2015, 2013 and 2014. The efficiency of agricultural enterprises in Serbia has been at a satisfactory level lately. This was positively influenced by a number of macro and micro factors, such as: general economic conditions, stable exchange rate, low inflation, low bank interest rate, subsidies and grants, reduced unemployment rate, increased living standards, regulation of the labor market of farmers, increasing understanding of the importance of insuring agriculture from adverse climate change, increased placement of agricultural products on foreign markets and branding of agricultural products. It plays a significant role the increasing production of organic products, the application of modern technology in agriculture, and the development of cooperatives.

Empirical research in this paper has shown that the WASPAS method is very suitable and simple for evaluating the efficiency of agricultural enterprises. Given that, as well as that there is a developed software program and available empirical data (Agency for Business Registers of the Republic of Serbia, Statistical Yearbook of the Republic of Serbia and others), it is recommended that it be used in the future to continuously evaluate the efficiency / performance of agricultural enterprises in Serbia. This provides an adequate basis for taking appropriate measures in order to achieve the target efficiency of agricultural enterprises in Serbia. 


\section{Conflict of interests}

The authors declare no conflict of interest.

\section{References}

1. Bakić, S. (2020). Banks' position from the aspect of financial indicators analysis. Oditor - časopis za menadžment, finansije i pravo, 6(2), 39-61. https://doi. org/10.5937/Oditor2002039B

2. Chakraborty, S., \& Zavadskas, E.K. (2014). Applications of WASPAS method in manufacturing decision making. Informatica, 25(1), 1- 20.

3. Chavas, J., \& Aiiber, M. (1993). An Analysis of Economic Efficiency in Agriculture: A Nonparametric Approach. Journal of Agricultural and Resource Economics, 18, 1-16.

4. Hafezalkotob, A., Hami-Dindar, A., Rabie, N., \& Hafezalkotob, A. (2018). A decision support system for agricultural machines and equipment selection: A case study on olive harvester machines. Computers and Electronics in Agriculture, 148, 207-216.

5. Kolagar, M. (2019). Adherence to Urban Agriculture in Order to Reach Sustainable Cities; a BWM-WASPAS Approach. Smart Cities, 2, 31-45.

6. Kutlu, G.F., \& Kahraman, C. (2019). Extension of WASPAS with spherical fuzzy sets. Informatica, 30(2), 269-292.

7. Lukic, R. (2011). Estimates of economic performance of organic food retail trade. Economic research, 24(3), 157-169.

8. Lukic, R., Lalic, S., Suceska, A., Hanic, A., \& Bugarcic, M. (2018). Carbon dioxide Emissions in retail food. Economics of Agriculture, 65(2), 859-874.

9. Lukic, R.\& Hadrovic-Zekic, B. (2019). Evaluation of efficiency of trade companies in Serbia using the DEA approach. Proceedings of the 19 th International Scientific Conference BUSINESS LOGISTICS IN MODERN MANAGEMENT October 10-11, Osijek, Croatia, Josip Juraj Strossmayer University of Osijek, Faculty of Economics in Osijek, 145-165.

10. Lukic, R, Hadrovic Zekic, B. \& Crnjac Milic, D. (2020a). Financial performance evaluation of trading companies in Serbia using the integrated Fuzzy AHP - TOPSIS Approach. 9th INTERNATIONAL SCIENTIFIC SYMPOSIUM REGION, ENTREPRENEURSHIP, DEVELOPMENT, Under the auspices of: REPUBLIC OF CROATIA MINISTRY OF SCIENCE AND EDUCATION, Osijek, June, 690-703.

11. Lukic, R., Vojteski Kljenak, D., \& Anđelić, S. (2020b). Analyzing financial performances and efficiency of the retail food in Serbia by using the AHP-TOPSIS method. Economics of Agriculture, 67(1), 55-68.

12. Lukic, R. (2020c). Analysis of the efficiency of trade in oil derivaties in Serbia by applying the Fuzzy AHP-TOPSIS method. Business Excellence and Management, 10(3), 80-98. 
13. Lukic, R., Hanic, H., \& Bugarcic, M. (2020d), Analysis of Profitability and Efficiency of Trade in Serbia. Economic Analysis, 53(2), 39-50.

14. Lukic, R. (2020e). Analysis of food retail efficiency in Serbia. Maso International, 1, 7-16.

15. Lukic, R., Vojteski Kljenak, D., \& Anđelic, S. (2020f). Analyzing financial performances and efficiency of the retail food in Serbia by using the AHP-TOPSIS method. Economics of Agriculture, 67(1), 55-68.

16. Petrovic, G., Mihajlovic, J., Cojbasic, Z., Madic, M., \& Marinkovic, D. (2019). Comparison of three fuzzy MCDM methods for solving the supplier selection problem. Facta Univ. Ser. Mech. Eng., 17, 455-469.

17. Saaty, T.L. (2008). Decision Making With The Analytic Hierarchy Process. Int J Serv Sci, 1(1), 83-98.

18. Turskis, Z., Zavadskas, E.K., Antucheviciene, J., \& Kosareva, K. (2015). A Hybrid Model Based on Fuzzy AHP and Fuzzy WASPAS for Construction Site Selection. International journal of compjuters communications \& control, 10(6), 113-128.

19. Urosevic, S., Karabasevic, D., Stanujkic, D., \& Maksimovic, M. (2017). An Approach Personel Selection in the Tourism Indystry Based on the SWARA and the WASPAS Methods. Economic computation and economic cybernetics studies and research, 51(1), 75-88.

20. Vojteski Kljenak, D., Lukic, R., Gavric, G., \& Gavrilovic, M. (2019). The operative margin and interest cost in retail food. Economics of Agriculture, 66(3), 799-810.

21. Zavadskas, E.K., Turskis, Z., Antucheviciene, J., \& Zakarevicius, A. (2012). Optimization of Weighted Aggregated Sum Product Assessment. Electronics and Electrical engineering, 6(122), 3-6.

22. Zavadskas, E.K., Antucheviciene, J., Saparauskas, J., \& Turskis, Z. (2013a). Multicriteria assessment of facades' alternatives: peculiarities of ranking methodology. Procedia Engineering, 57, 107-112.

23. Zavadskas, E.K., Antucheviciene, J., Saparauskas, J., \& Turskis, Z. (2013b). MCDM methods WASPAS and MULTIMOORA: verification of robustness of methods when assessing alternative solutions. Economic Computation and Economic Cybernetics Studies and Research, 47(2), 5-20.

24. Zhang, H., Guo, S., Qian, Y., Liu, Y., \& Lu, C. (2020). Dynamic analysis of agricultural carbon emissions efficiency in Chinese provinces along the Belt and Road. PLoS ONE, 15(2), e0228223. https://doi.org/10.1371/journal.pone.0228223 